\title{
SPATIALISED AGRICULTURAL NITROGEN BALANCE OF VENETO REGION, NORTHERN ITALY: SOURCES IDENTIFICATION, ASSESSMENT AND POLICY RELEVANCE
}

\section{PULIGHE G. VANINO $S$. LUPIA F. \\ ALTOBELLI F.}

Received: 17/09/2013

Accepted: $11 / 03 / 2014$

Available online: 13/03/2014
Istituto Nazionale di Economia Agraria

Via Nomentana 41, 00161 Roma, Italy

\section{ABSTRACT}

The aim of this study is to deepening knowledge on the agricultural nitrogen cycle within the Veneto region (Northern Italy) by computing the Gross Nitrogen Balance (GNB) with highly geographical resolution. Spatialised maps of nitrogen input and output, created using the most detailed information available, are important tools for assessing environmental sustainability.

Nitrogen mass balances, computed at regional level for 2007, suggest a large $\mathrm{N}$ surplus in this area, over $82,485 \mathrm{t} \mathrm{N}$ year $^{-1}$. Calculations indicate a large impact of animal husbandry and agricultural activities in this region, with livestock manure and synthetic fertilizers contributing $87.7 \%$ of total $\mathrm{N}$ inputs (about 208,050 t N year $^{-1}$ ), largely exceeding $N$ outputs (about 1,255,644 t N year ${ }^{-1}$ ). The GIS-based analysis highlights interdependencies between farmer's choices of land uses and the environmental pressures of agricultural activities at the sub-regional level. The results of the study can be used to inform policy makers about the effects caused by environmental management actions that should take into account the interlinkages between landscapes, habitats, biodiversity and ecological integrity.

Keywords: Gross Nitrogen Balance, Agro-environmental Land Units, GIS-based spatialisation, Veneto region, policy relevance

\section{Introduction}

The human imprint on the nitrogen $(\mathrm{N})$ cycle represents a major example of global geo-engineering and have become a topic of increasing research attention in recent years (Sheldrick et al., 2002; Gruber and Galloway, 2008). With reactive nitrogen ( $\mathrm{Nr}$ ), defined as all other nitrogen forms in earth-system apart from $\mathrm{N}_{2}$, humanity has managed to feed the world, but at the same time has created a complex web of impacts that is causing multiple effects of global change (Sutton et al., 2011).

Environmental problems related to the cascading effects of $\mathrm{Nr}$ concern all economic sectors and impacts on the atmosphere, pedosphere, hydrosphere and anthroposphere, with compelling evidence that human alteration of the $\mathrm{N}$ cycle is negatively affecting human and ecosystem health, thus is considered the third major threat to our planet, after biodiversity loss and climate change (Giles, 2005; Galloway et al., 2008).

The engineering efforts for atmospheric nitrogen fixation have more than doubled the global production of $\mathrm{Nr}$ compared with pre-industrial levels, reflecting an increased combustion of fossil fuels, growing

Pulighe G., Vanino S., Lupia F. and Altobelli F. (2014), Spatialised agricultural nitrogen balance of Veneto region, Northern Italy: sources identification, assessment and policy relevance, Global NEST Journal, 16(2), 293-305. 
demand for nitrogen in agriculture and industry and widespread inefficiencies in its use (Galloway et al., 2008), having consequences that could not have been foreseen a century ago (Sutton et al., 2011).

Reactive nitrogen compounds include inorganic chemically reduced forms of $\mathrm{N}\left(\mathrm{NH}_{\mathrm{x}}\right)$ [e.g., ammonia $\left(\mathrm{NH}_{3}\right)$ and ammonium ion $\left(\mathrm{NH}_{4}{ }^{+}\right)$], inorganic chemically oxidized forms [e.g., nitrogen oxides $\left(\mathrm{NO}_{\mathrm{x}}\right)$, nitric acid $\left(\mathrm{HMO}_{3}\right)$, nitrous oxide $\left(\mathrm{N}_{2} \mathrm{O}\right), \mathrm{N}_{2} \mathrm{O}_{5}, \mathrm{HONO}$, peroxy acetyl compounds such as peroxyacytyl nitrate (PAN), and nitrate ion $\left(\mathrm{NO}_{3}^{-}\right)$], as well as organic compounds (e.g., urea, amines, amino acids, and proteins), (U.S. EPA, 2011).

Excess reactive forms of nitrogen are capable of cascading through the environment causing a number of ecological and human health effects, like acidification, eutrophication of surface waters and biodiversity impacts (de Vries et al., 2011).

Changes in land use and landscape pattern, soil sealing and intensive agricultural practices have simplified the landscape diversity and removed buffer strips and corridors as non-crop vegetated filter zones and wetlands (hedgerows, riparian strips, slow flowing meanders, ponds, etc.). The absence of these elements has further exacerbated nitrogen migration and made the surface and groundwater more prone to nitrogen contamination (Cey et al., 1999; Borin et al., 2010; Balestrini et al., 2011; Bartoli et al., 2012). Therefore, understanding the pathway and storage potential of nitrogen is needed to gain a comprehensive picture of the state conditions, and helps us understand how ecosystems respond to anthropogenic pressures. European agricultural systems (EU-27) receive the highest Nr inputs (c.a. $18 \mathrm{Tg}$ $\mathrm{N}$ year ${ }^{-1}$ reactive nitrogen), but it is estimated that only $39 \%$ of applied $\mathrm{N}$ (c.a. $7 \mathrm{Tg} \mathrm{N}$ year ${ }^{-1}$ ) finds its way to consumers or is further processed industrially (Leip et al., 2011a). The European Environmental Agency (EEA) and the Organisation for Economic Co-operation and Development (OECD) indicates that the gross nitrogen balance in 2000 (EU-15 level) was calculated to be $55 \mathrm{~kg} \mathrm{ha}^{-1}$, which is $16 \%$ lower than the balance estimate in 1990, which was $66 \mathrm{~kg} \mathrm{ha}^{-1}$. In 2000 the gross nitrogen balance ranged from 37 $\mathrm{kg} \mathrm{ha}^{-1}$ (Italy) to $226 \mathrm{~kg} \mathrm{ha}^{-1}$ (the Netherlands). All national gross nitrogen balances show a decline in estimates of the gross nitrogen balance $\left(\mathrm{kg} \mathrm{ha}^{-1}\right.$ ) between 1990 and 2000, apart from Ireland (22\% increase) and Spain (47\% increase).

The gross nitrogen balance indicator can be used as a proxy to reveal the status of environmental pressures, and provides an insight of the links between agricultural nitrogen use, $\mathrm{N}$ losses to the environment, and the sustainable use of soil $\mathrm{N}$ resources.

However, the national balance can mask important local differences, for example in areas with high livestock concentrations, determining the actual nitrogen leaching risk at regional or local scale. UE Member States can thus have an acceptable nitrogen balance at a national scale, but significant and diverse experiences of nitrogen pollution at regional or local scales (Pieri et al., 2011). These regional hotspots of high gross nitrogen balances can lead to environmental pressures.

Previous studies at watershed level report a wide variability of yearly $\mathrm{N}$ balance, from less than 10 $\mathrm{kg} \mathrm{ha}^{-1}$ (Beaudoin et al., 2005) to $180 \mathrm{~kg} \mathrm{ha}^{-1}$ (Bartoli et al., 2012). This is probably due to both the characteristics of the sites, the production management methods and the fertilizers efficiency. Addressing open research questions about the pathway of the nitrogen input and output implies needs to answer where and for how long does the excess nitrogen accumulate (Soana et al., 2011; Bartoli et al., 2012). The interrelationships between these questions are manifold and encompass the processes and the transformation that nitrogen undergoes in the environment across the soil-water-atmosphere system. (Leip, 2011b).

There is still an insufficient understanding of the finer details of these processes, thus, the identification of areas with heavy nitrogen loads and the characterization of nitrogen sources are important indicators for land use planners and environmental managers and for hydrographic basin management (Di Lorenzo et al., 2012). In addition, as pointed out by Oenema et al. (2003) and Campling et al. (2005), agroenvironmental indicators need to be based on sound science to understand the cause-effect chain and to be really informative and useful for the policy responses. 
De Vries et al. (2011) presented three different budgetary approaches to quantify $\mathrm{N}$ balances in regional agricultural systems, using the farm, soil or land as the gate at which the $\mathrm{N}$ inputs and outputs are quantified. Farm nitrogen budget records the amounts of $\mathrm{N}$ in all kinds of products that enter and leave the farm via the farm-gate. Soil nitrogen budget records all $N$ that enters the soil and that leaves the soil via crop uptake, including nutrient gains and losses within the soil.

In this paper we implement an approach for the spatialisation of $\mathrm{N}$ budget for agro-ecosystems using budgeting approaches by land nitrogen budget (called gross $N$ balances by OECD (OECD, 2007)). The balance records all $\mathrm{N}$ that enters at farm land and leaves the farmland by harvested products. Nitrogen inputs include fertilizer, animal manure production and excretion, biological $\mathrm{N}$ fixation and $\mathrm{N}$ deposition. The $\mathrm{N}$ surplus is not further specified, as well as $\mathrm{N}$ losses from the manure storage systems and from soil to the air and to aquatic systems ( $\mathrm{N}$ emissions, $\mathrm{N}$ leaching and runoff), that can be specified in a detailed land system budget (de Vries, 2011). This approach is used by the OECD as environmental performance indicator for agriculture (OECD, 2007), and is currently the best available measure for potential nutrient leaching risk.

In this context, the study tries to extend and improve the knowledge of the agricultural $\mathrm{N}$ budget in the large catchment of the Veneto region (Po River Plain). We analyzed this region due to its elevated human population and farmed animal densities, maize-oriented intensive agriculture, highly permeable soils, landscape simplification and intensive irrigation practices. The study was also made possible thanks to the availability of reliable, spatially detailed and easily accessible data of the Veneto region, that has an advanced regional spatial data infrastructure.

Analysis of the nitrogen budget and detailed understanding of pathways of nitrogen are particularly relevant in this region, which is one of the most exploited area of Italy for farming and agriculture, with an estimated 740,000 pigs and 150,000 cows ( 8.4 and $42 \%$ of national production, respectively) (ISTAT, 2010). Moreover, $62 \%$ of Veneto plain is declared as vulnerable to nitrate pollution.

Therefore, the specific objectives of this research are:

(i) To give an overview of the $\mathrm{N}$-fluxes of agro-ecosystems in the Veneto region compiling a number of 'key maps' of the main $\mathrm{N}$-sources;

(ii) To show aggregate fluxes of nitrogen and assess nitrogen balance;

(iii) To discuss the policy relevance and effectiveness of the spatialised nitrogen budget for the agroenvironmental management.

\section{Materials and methods}

\subsection{Study area}

The Veneto region lies in North-Eastern Italy, between $44^{\circ} 47^{\prime}$ and $46^{\circ} 41^{\prime} \mathrm{N}$ and $10^{\circ} 37^{\prime}$ and $13^{\circ} 06^{\prime} \mathrm{E}$, with a total surface of about $18,390 \mathrm{~km}^{2}$ (Figure 1). The region can be broadly divided into natural zones in the following order, from north to south: a) the alpine zone, characterized by forestry and natural areas b) prealpine (from 700 to 2,000 m) with large parts of the pasture, meadows and livestock, c) area subalpine hills, with significant extensions of vineyards and smaller orchard, d) area of lowlands, characterized by highly specialized intensive farming, e) coastal plain and lagoon area. The lowland areas are prevalent (56\% of the land area), followed by the mountain areas (29\%) and hilly areas (15\%), while the Utilized Agricultural Area (UAA) accounts for 807,472 ha.

Land use is dominated by agricultural areas with an intensive multi-cropping system that include maize $(320,000 \mathrm{ha})$, orchards $(112,000 \mathrm{ha})$, pastures $(55,000 \mathrm{ha})$, vegetables $(15,000 \mathrm{ha})$ and integrated livestock breeding. Water management in agriculture is carried out by ten Land Reclamation Consortia.

The region is crossed by a complex network of rivers flowing into the Adriatic Sea. Average annual precipitation ranges between about $700 \mathrm{~mm}$ in the lowlands to $3,000 \mathrm{~mm}$ in the foothills of the Alps (Piano di gestione dei bacini idrografici delle Alpi Orientali, 2010). The region has a high population 
density (4.8 million inhabitants; $7.9 \%$ of total population), significantly higher than the rest of Italy (260 residents $\mathrm{km}^{2}$, compared to the national average of 196 inhabitants $\mathrm{km}^{2}$ ), and is one of the most industrialized areas of Italy (ISTAT, 2011). The population is concentrated in the plains and hills, giving rise to a settlement pattern of urban sprawl.

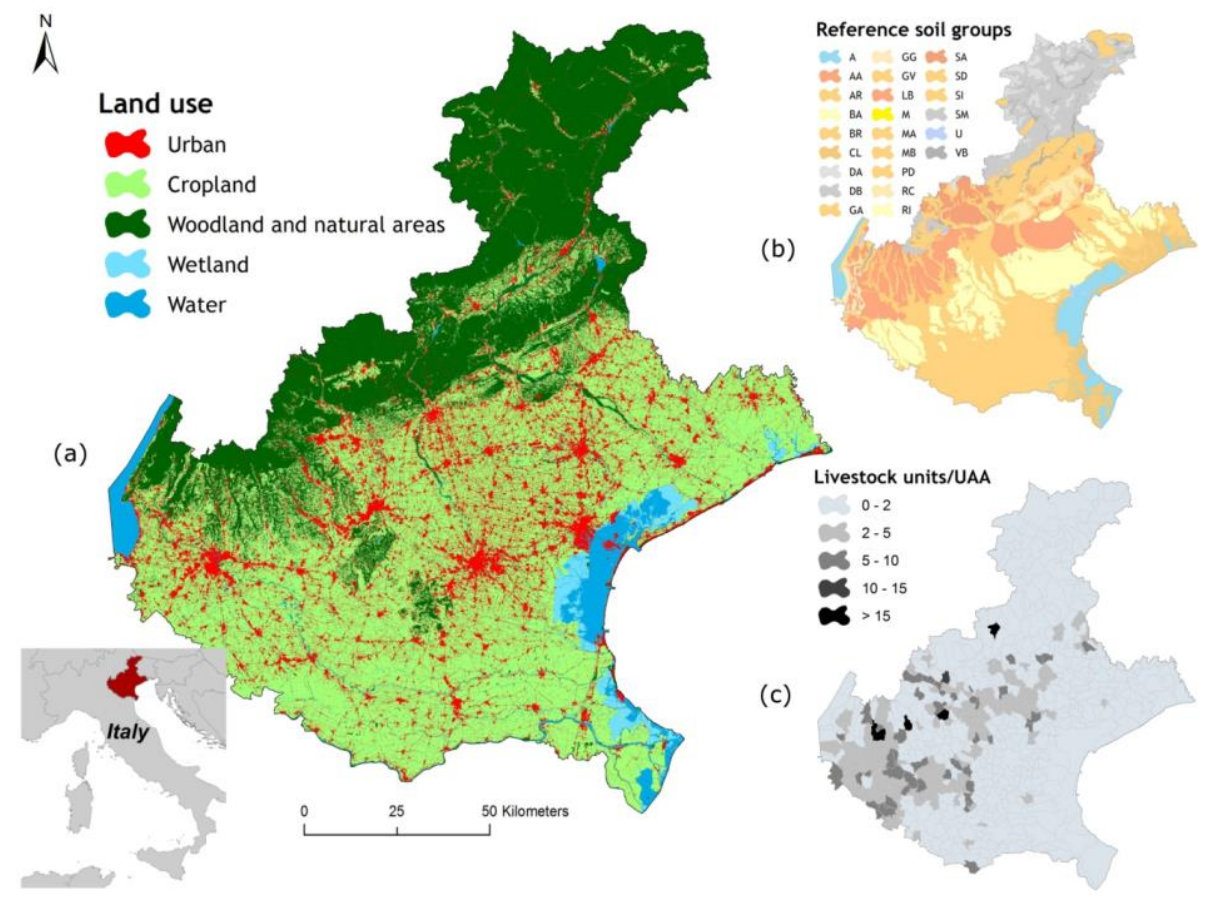

Figure 1. Study area (a) and land use type; (b) Reference soil groups; (c) Livestock density

\subsection{Geographical identification of Land Units}

In order to accurately spatialise the data set, the study area was divided into different Agroenvironmental Land Units (ALU), as described in Bassanino et al., (2011) and Lassaletta et al., (2012), according to their land use and farming system, livestock, hydrographic and geomorphologic characteristics. To do so, a digital intersection of the maps of main land uses, livestock units and soil regions was done using Geographical Information System (GIS).

Table 1. Basic data used and their sources.

\begin{tabular}{ccc}
\hline Data & Source & Spatial/thematic resolution \\
\hline Land use map & Regione Veneto & $1: 10000$ \\
\hline Soil type map & Regione Veneto & $1: 250000$ \\
\hline Municipality borders & Regione Veneto & $1: 10000$ \\
\hline Fertilizer consumption & ISTAT & Province level \\
\hline Fertilizer application rate & Regione Veneto & Crops level \\
\hline N crop uptake & Regione Veneto & Crops level \\
\hline Crop yield & ISTAT & Province level \\
\hline Livestock units & ISTAT & Municipal level \\
\hline N excretion rate & CRPA & Livestock level \\
\hline N deposition map & EMEP & $50 \times 50 \mathrm{~km}$ \\
\hline
\end{tabular}

Thematic datasets and metadata services are available from the geo-portals of Veneto region and ISTAT (Italian National Institute of Statistics.). Data sources used in the study are given in Table 1. 
Data combination allowed the identification of four distinct homogeneous units (Figure 1).

The boundaries were then slightly modified to adapt the units to the municipality borders, to enable further joining with other datasets. In the Veneto region there are 581 municipalities. ALUs represent the homogeneous units of land that we geographically identified at the regional scale in terms of agricultural use, soil type and geomorphologic characteristics.

ALU1 (13\% of the total surface), is the most intensively managed of the ALUs (mainly maize-based) and high livestock densities (3.36 LU). (Table 2).

Table 2. Main characteristics of the Agro-environmental Land Units (ALU).

\begin{tabular}{cccccccc}
\hline ALU & $\begin{array}{c}\text { Surface } \\
\text { ha }\end{array}$ & $\begin{array}{c}\text { Agricultural } \\
\text { land (\%) }\end{array}$ & $\begin{array}{c}\text { Natural } \\
\text { areas (\%) }\end{array}$ & $\begin{array}{c}\text { Urban } \\
(\%)\end{array}$ & $\begin{array}{c}\text { Water and } \\
\text { wetlands } \\
(\%)\end{array}$ & LU & LU/UAA \\
\hline 1 & 235051 & 72 & 4.27 & 19.81 & 1.22 & 593219 & 3.36 \\
\hline 2 & 634328 & 64 & 2.16 & 15.53 & 13.80 & 260893 & 0.60 \\
\hline 3 & 444201 & 58.41 & 19.50 & 17.64 & 4.44 & 439492 & 1.69 \\
\hline 4 & 527995 & 19.68 & 75.41 & 4.32 & 0.58 & 78900 & 0.73 \\
\hline Total & 1841575 & 52.86 & 27.61 & 13.37 & 6.15 & 1372504 & 1.4 \\
\hline
\end{tabular}

ALU2 (34.4\% of the total surface), is characterized by a high proportion of irrigated agriculture and low livestock densities $(0.6 \mathrm{LU})$, high proportion of water and wetlands.

ALU3 (24\% of the total surface), have relatively high livestock densities (1.69 LU) and cultivation is characterized by vineyards and orchards.

ALU4 ( $28,6 \%$ of the total surface), is characterized by low agricultural surfaces and livestock densities (0.73 LU), high proportion of pastures, meadows and natural environments. Once the ALUs were spatially defined, the gross nitrogen balance in each ALU was calculated. The differences between ALUs, both in terms of nitrogen inputs and outputs results were statistically analysed using the software IBM SPSS Statistics 20.

\subsection{Land nitrogen budgets}

The nitrogen budget is a mass balance between nutrients inputs to the soil from agricultural and natural sources, and nutrients exported with the harvested crops, forages and pastures. The indicator was selected by OECD intended specifically to identify environmental issues related to agriculture and to help monitor and assess agro-environmental policies (CEC, 2000). The indicator was also known as IRENA Indicator Fact Sheet 18.1 - Gross Nitrogen Balance (Indicator Reporting on the Integration of Environmental Concerns into Agricultural Policy).

Gross nitrogen balance was calculated according to the following equation:

$\mathrm{GNB}=\mathrm{N}_{\text {fer }}+\mathrm{N}_{\mathrm{man}}+\mathrm{N}_{\text {fix }}+\mathrm{N}_{\text {dep }}-\mathrm{N}_{\text {har }}$

where GNB is the gross nitrogen balance surplus, $N_{\text {fer }}$ is the synthetic fertilizers application, $N_{\text {man }}$ is the manure application, $\mathrm{N}_{\mathrm{fix}}$ is the biological $\mathrm{N}$ fixation (occurring in leguminosae species), $\mathrm{N}_{\text {dep }}$ is the atmospheric $\mathrm{N}$ deposition (reduced and oxidized compounds), and $\mathrm{N}_{\text {har }}$ is the removal of nitrogen with harvest and grazing of crops and forage. The indicator estimates the potential surplus of nitrogen on agricultural land.

Positive values of the difference between inputs and the outputs corresponds to the agricultural surplus, which is the potential source of diffuse pollution to the water and the atmosphere. Negative values (removal exceeds use) lead to declining soil fertility and eventually to reduced productivity once nutrient supplies drop below critical levels. Zero values (use equals removal) is usually associated with soil fertility maintenance. 
Apart from long-term sustainable productivity, well balanced nitrogen management can improve the crop removal efficiency and the availability of other nutrients, improves soil reaction and structure and can lower the indirect toxicity of aluminum and manganese (FAO, 2000; Fageria et al., 2010).

Detailed $\mathrm{N}$ inputs and outputs derived from the available database were spatialised using GIS functions for the reference year 2007. Nitrogen from inorganic fertilizers was calculated by multiplying the fertilizer application rate recommended for the Veneto region (Regione Veneto, 2012) for each crop with the corresponding land use area.

In order to ensure consistency with total volume calculated, the data was cross-checked with the estimated consumption provided by ISTAT for the year 2007. The total amount was considered uniformly distributed within each class of land use.

Nitrogen from manure was calculated starting from detailed information of livestock units (LU) on bovine, porcine, ovine, caprine and avian provided by ISTAT at the municipal level for the year 2010, since the data for 2007 are organized at the provincial level. The assumption was verified by comparing the total amount of LU for both years, and has showed similar values.

Livestock unit is a reference unit used for aggregating the numbers of different categories of livestock from various species and age, usually derived in terms of relative feed requirements. Conversion ratios are generally based on metabolisable energy requirements, with one unit being considered as the needs for maintenance and production of a typical dairy cow and calf (FAO, 2011).

Estimate $\mathrm{N}$ inputs from manure was assumed homogeneously spread to all crops in the municipalities. They correspond to a total of 1,372,504 livestock units, heterogeneously distributed over the study area. This assumption was adopted by Saam et al. (2005) and Bassanino et al. (2011) considering that legislation requiring to delocalise excess farm manure to surrounding neighborhoods to better balance manure $\mathrm{N}$ load at the territorial scale. Manure $\mathrm{N}\left(\mathrm{N}_{\operatorname{man}}\right)$ production of nitrogen in kilograms produced per year is therefore equal to:

$\mathrm{N}_{\text {man }}=\sum_{1}^{\mathrm{n}}\left(\mathrm{LU}^{*} \alpha\right)$

where $L U$ is the livestock density index measures the stock of animals per hectare. It is the ratio of the number of livestock units per hectare of utilised agricultural area (UAA); $\alpha$ is a coefficient expressing nitrogen excretion rates $\left(\mathrm{kg}_{\text {head }}{ }^{-1}\right.$ year ${ }^{-1}$ ), specific for the Italian territory (CRPA, 2006), while $n$ is the number of livestock categories.

Biological $\mathrm{N}$ fixation by legume crops and forage legume species was calculated through the model adopted by Lassaletta et al. (2012), that relates crop yield, $N$ fertilization and crop residues. The equation adopted is the following:

$N_{\text {fix }}=\alpha^{*} N_{\text {yeld }}-A$

where $\mathrm{N}_{\text {yield }}$ is the harvested biomass expressed in $\mathrm{N}$ content $\left(\mathrm{kg} \mathrm{ha}^{-1} \mathrm{year}^{-1}\right) ; \alpha$ is a coefficient expressing the ratio between the total biomass produced and the harvested biomass and $\mathrm{A}$ is the amount of $\mathrm{N}$ uptaken by the legume crop from the $\mathrm{N}$ soil amount prior to nodulation. The formula considers the fact that in the period prior to nodulation, legumes obtained the entire external $\mathrm{N}$ from mineral nitrogen present in the soil, while only after nodulation $\mathrm{N}$ is progressively assimilated from $\mathrm{N}_{2}$ fixation.

Basal application at the rate of $30 \mathrm{~kg} \mathrm{~N} \mathrm{ha}^{-1}$ was recognized for soybean (Boroomandan et al., 2009) which acts as a "starter effect" without damaging the root tubercles.

Atmospheric $\mathrm{N}$ deposition originates mainly from combustion of fossil fuel (industrial, motor veicles) and agricultural sources. Spatialised information on deposition of oxidized and reduced $\mathrm{N}$ compounds was extracted from the data provided by the Co-operative Programme for Monitoring and Evaluation of the Long-range Transmission of Air Pollutants in Europe (EMEP), measured at permanent stations, at a $50 \times 50 \mathrm{~km}$ resolution (EMEP, 2000). 
Nitrogen crop removal calculation was based on the $\mathrm{N}$ yield of each crop and on the $\mathrm{N}$ content of the harvested products obtained by regional database reporting values for each crop and by product (Regione Veneto, 2012).

The total crops yields, reported at province level, were derived from crop production statistics, collected by ISTAT yearly at province level. In addition, Nitrogen Use Efficiency (NUE) was also calculated by dividing the $\mathrm{N}$ in the harvested crops by the estimates of the $\mathrm{N}$ inputs (Liu et al., 2008) expressed as a percentage of the $\mathrm{N}$ synthetic fertilizer and manure. In the calculation of NUE, $\mathrm{N}$ deposition and $\mathrm{N}$ biological fixation of leguminous crops was excluded, because for these crops is not a meaningful concept (Bouwman et al., 2005).

In order to spatialise inputs and outputs data, we used a detailed land use vector map of Veneto region with a scale of 1:10,000 with a legend structured according to Corine Land Cover legend, having 41 categories. The association between land use classes and crop statistics was made by defining an appropriate matching table. For some land use classes an aggregation of crops was made, in order to ensure the full matching with the two datasets. The resolution of land use map and the association of classes do not affect the evaluation of the nitrogen balance at the regional level or ALUs because calculations have previously been performed in a database. However, small errors in the spatialisation may be due to the fact that it is not possible to associate all crop statistics with all land uses, especially for vegetables. GIS functions allows to derived spatialised maps of fertilizer inputs, manure, biological $\mathrm{N}$ fixation, $\mathrm{N}$ deposition, crop uptake and nitrogen surplus.

\section{Results and discussion}

\subsection{Spatialisation in Agro-environmental Land Units}

According to the equation (1), the annual $N$ input of the Veneto region is high $\left(208,049.89 \mathrm{t} \mathrm{N}\right.$ year $\left.{ }^{-1}\right)$ (Table 3). Synthetic fertilizers are the largest contributor of nitrogen to the agricultural lands $\left(121,015.94 \mathrm{t}\right.$ year $\left.{ }^{-1}\right)$, followed by manure $\left(61,420.93 \mathrm{t}\right.$ year $\left.\mathrm{r}^{-1}\right)$, atmospheric deposition $(18,238.78$ $\left.\mathrm{t}^{\text {year }} \mathrm{r}^{-1}\right)$ and finally biological fixation $\left(7,374.23 \mathrm{t} \mathrm{year}^{-1}\right)$.

Table 3. Total quantities of nitrogen inputs, outputs and surplus for the ALUs. (The figures in brackets are the $\%$ of each input to the total inputs for each ALU) ( $\left.\mathrm{N} \mathrm{year}^{-1}\right)$.

\begin{tabular}{ccccccccc}
\hline \multirow{2}{*}{ ALU } & Total input & $\begin{array}{c}\text { Synthetic } \\
\text { fertilizers }\end{array}$ & Manure & $\begin{array}{c}\text { N-biological } \\
\text { fixation }\end{array}$ & $\begin{array}{c}\text { N- } \\
\text { deposition }\end{array}$ & Output & $\begin{array}{c}\text { Agriculture } \\
\text { surplus }\end{array}$ & $\begin{array}{c}\text { N-efficiency } \\
\%\end{array}$ \\
\hline \multirow{2}{*}{5} & \multirow{2}{*}{57074.29} & $\begin{array}{c}25814.02 \\
(45 \%)\end{array}$ & $\begin{array}{c}26078.07 \\
(46 \%)\end{array}$ & $\begin{array}{c}1266.12 \\
(2 \%)\end{array}$ & $\begin{array}{c}3916.08 \\
(7 \%)\end{array}$ & 23921.52 & 33039.16 & 0.46 \\
\hline 2 & \multirow{2}{*}{86174.83} & $\begin{array}{c}61605.09 \\
(72 \%)\end{array}$ & $\begin{array}{c}13355.82 \\
(15 \%)\end{array}$ & $\begin{array}{c}3675.57 \\
(4 \%)\end{array}$ & $\begin{array}{c}7538.35 \\
(9 \%)\end{array}$ & 65760.45 & 20113.88 & 0.88 \\
\hline 3 & \multirow{2}{*}{53320.93} & $\begin{array}{c}28101.31 \\
(53 \%)\end{array}$ & $\begin{array}{c}17865.12 \\
(34 \%)\end{array}$ & $\begin{array}{c}2358.93 \\
(4 \%)\end{array}$ & $\begin{array}{c}4995.56 \\
(9 \%)\end{array}$ & 30775.38 & 22451.58 & 0.67 \\
\hline \multirow{2}{*}{11412.57} & $\begin{array}{c}5495.52 \\
(48 \%)\end{array}$ & $\begin{array}{c}4121.92 \\
(36 \%)\end{array}$ & $\begin{array}{c}73.60 \\
(0,6 \%)\end{array}$ & $\begin{array}{c}1721.52 \\
(15,5 \%)\end{array}$ & 5107.13 & 6305.44 & 0.53 \\
\hline Total & 208049.89 & 121015.94 & 61420.93 & 7374.23 & 18238.78 & 125564.49 & 8248540.1 & 0.69 \\
\hline
\end{tabular}

The results shows large spatial variability of $\mathrm{N}$ inputs due to land use and agricultural practices, with higher loads located in more intensive ALUs (Figure 2). 


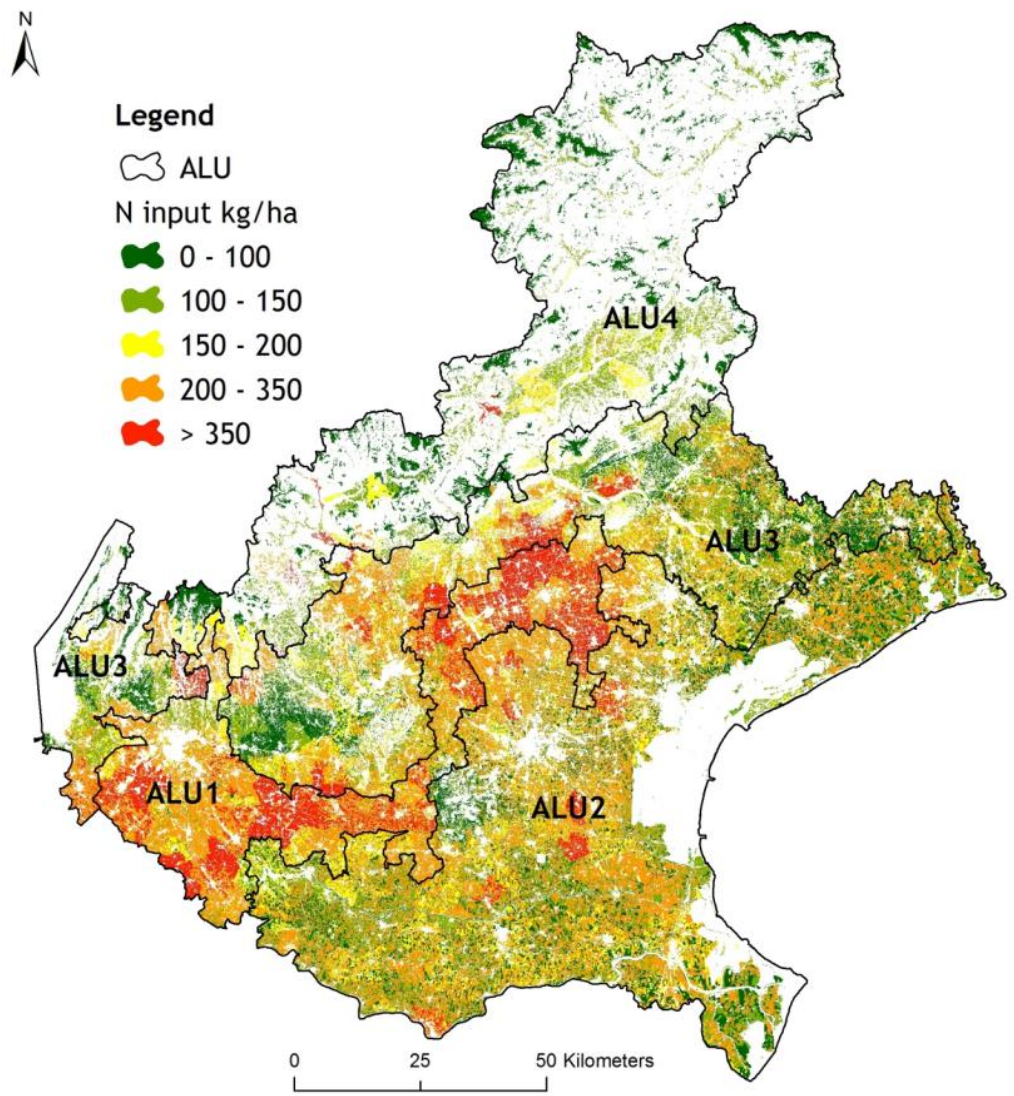

Figure 2. Spatialised $\mathrm{N}$ inputs in the Veneto region

The annual $\mathrm{N}$ input in ALU1, characterized by high livestock densities, is very high $\left(57,074.29 \mathrm{t} \mathrm{N}\right.$ year $\left.{ }^{-1}\right)$, while synthetic fertilizers and manure contribute with $45 \%$ and $46 \%$ of the total, respectively. The nitrogen surplus is $33,039 \mathrm{t} \mathrm{N}^{\mathrm{N}}$ year ${ }^{-1}$.

ALU2 shows the highest level of nutrient input $\left(86,174.83 \mathrm{t} \mathrm{N} \mathrm{year}{ }^{-1}\right)$ mainly due to high mineral inputs $\left(61,605.09 \mathrm{t} \mathrm{N} \mathrm{ha}^{-1}\right)$, covering $72 \%$ of the total input. The nitrogen surplus is $20,114 \mathrm{t} \mathrm{N}$ year ${ }^{-1}$. The annual $\mathrm{N}$ input in ALU3 is high $\left(53,320.93 \mathrm{t} \mathrm{N}\right.$ year $\left.^{-1}\right)$, while synthetic fertilizers and manure contribute with $53 \%$ and $34 \%$ of the total, respectively. The nitrogen surplus is $22,545 \mathrm{t} \mathrm{N}$ year $^{-1}$.

ALU4 shows the lowest nitrogen input among ALUs $\left(11,412.57 \mathrm{t} \mathrm{N}\right.$ year $\left.{ }^{-1}\right)$, while synthetic fertilizers and manure contribute with $45 \%$ and $46 \%$ of the total, respectively. The nitrogen surplus is $6,305.44 \mathrm{t} \mathrm{N}$ year ${ }^{-1}$.

$\mathrm{N}$ input from biological fixation does not vary much among the ALUs, with low values in ALU4, where grassland, pastures and natural areas are the most relevant land uses, while soybean and other leguminous crops are more important in ALU2 and ALU3.

The calculation of nutrient budget indicators suggests that Veneto region displays a net surplus for all the main nutrients. However, substantial differences among different agro-environments unit exist, with hotspots of high gross nitrogen balances that can lead to environmental pressures.

These differences in the ALUs and NUE can be explained by the characteristics of the agricultural systems. Maize-based agricultural systems like ALU1 is often over-fertilized with large quantities of manure and fertilizer, independent of the product collected from the field (Bassanino et al., 2011; Ronaghi and Ghasemi-Fasaei, 2013). Moreover, the relatively low cost of applying and pressure to maximise yields it is far outweighed by the extra value of crop obtained, resulting in over-rather than undersupply (Kitchen and Goulding, 2001; Stark and Richards, 2008). These agricultural systems are 
often associated with livestock concentrated at high stocking density, especially for pigs, poultry and to lesser extent dairy cattle (Gaj and Bellaloui, 2012).

Table 4 reports the mean values of nitrogen budget results for each ALU in $\mathrm{kg} \mathrm{ha}^{-1}$ year $^{-1}$. Our analysis revealed that nitrogen surplus is mainly related to the application of manure per hectare of total ALU. In fact, ALU1 shows the lower value of NUE (0.46) due to the high incidence of manure $\left(152.1 \mathrm{~kg} \mathrm{~N}\right.$ year $\left.{ }^{-1}\right)$. The over-application generally decreases nitrogen use efficiency and is related to a higher risk of losses compared to mineral fertilizers (Liu et al., 2008; Spiess, 2011). This is partially explained by difficulties of manure collection, storage, transportation and application (Gourley et al., 2012).

Table 4. Mean values of nitrogen inputs, outputs and surplus for the ALUs. (Standard deviation is calculated between municipalities in each ALU) $\left(\mathrm{kg} \mathrm{N} \mathrm{ha}^{-1}\right.$ year $\left.^{-1}\right)$.

\begin{tabular}{cccccccc}
\hline ALU & $\begin{array}{c}\text { Syntetic } \\
\text { fertilizers }\end{array}$ & Manure & $\begin{array}{c}\text { N-biological } \\
\text { fixation }\end{array}$ & N-deposition & Output & $\begin{array}{c}\text { Agriculture } \\
\text { surplus }\end{array}$ & SD \\
\hline 1 & 150.6 & 152.1 & 7.4 & 22.8 & 139.6 & 192.7 & 102.2 \\
\hline 2 & 147.1 & 31.9 & 8.8 & 18 & 157.1 & 48 & 45.9 \\
\hline 3 & 110.5 & 70.3 & 9.3 & 19.6 & 121.1 & 88.3 & 104.9 \\
\hline 4 & 52.9 & 39.7 & 0.7 & 17.2 & 49.2 & 60.7 & 103.4 \\
\hline Total & 127.6 & 64.8 & 7.8 & 19.2 & 132.4 & 86.4 & 99.0 \\
\hline
\end{tabular}

Crop type and $\mathrm{N}$ removal by crop is further crucial, and differences among ALUs and NUE can also be explained by the mix of crops. ALU2 has a large proportion of crops with high $\mathrm{N}$ crop removal (e.g. irrigated crops, soybean and tobacco), and show high values for the $\mathrm{N}$ removal (157.1 kg N year ${ }^{-1}$ ) and NUE (0.88\%). These crops have no water limitation and the threshold at which they do not respond to new $\mathrm{N}$ additions is higher than that of rainfed agriculture (Lassaletta et al. 2012). This interpretation is in accordance with Aarts et al. (2000), Langeveld et al. (2007) and Ki-In Kim et al. (2008) that have reported the synergistic relationships occurring between water and $\mathrm{N}$, where improved irrigation water management can enhance $\mathrm{N}$ uptake, and thereby reduce $\mathrm{N}$ losses.

ALU3 shows the second highest level of synthetic fertilizers and manure (110.5 and $70.3 \mathrm{~kg} \mathrm{~N} \mathrm{ha}^{-1}$ year ${ }^{-1}$, respectively). This agro-environment comprises predominantly orchards and vineyards, oriented towards specific productions of high quality requiring well-balanced $\mathrm{N}$ management practices.

ALU4 shows the lowest level of output (49.2 kg N ha year $\left.{ }^{-1}\right)$ and lowest surplus $\left(60.7 \mathrm{~kg} \mathrm{~N}\right.$ ha year $\left.{ }^{-1}\right)$, having a large share of grassland and pastures with low farm stocking rates.

Regional total $\mathrm{N}$ inputs for all the ALUs combined reported surpluses of $86.4 \mathrm{~kg} \mathrm{ha}^{-1}$ for $\mathrm{N}$, much higher than the national estimate of $33 \mathrm{~kg} \mathrm{~N} \mathrm{ha}^{-1}$ for the year 2008 (EUROSTAT, 2013), while the NUE is 0.69 (Table 3). Similar values were also found from environmental planning studies of Veneto region (Regione Veneto, 2009) that report an estimated surplus of $98.1 \mathrm{~kg} \mathrm{ha}^{-1}$ year $^{-1}$, with the contribution of manure and fertilizer of 70 and $122.4 \mathrm{~kg} \mathrm{ha}^{-1}$ year $^{-1}$, respectively.

\subsection{Policy relevance}

To tackle the growing environmental problems, since the early 90's several agro-environmental policies have been directed towards trying to reduce environmental impacts, protect water quality, reduce overproduction and improve rural development (e.g. Common Agricultural Policy (CAP), EU Nitrates Directive (91/676/EEC), Water Framework Directive (2000/60/EC), Council Regulations (EC) Reg. 92/1765/EEC, Reg. 92/2078/EEC and Reg. 1698/2005). The gross nitrogen balance is an indicator to evaluate the environmental impacts of these policy measures, providing warnings about the potential risk of nitrogen loadings. In fact, water contamination by nitrates is one of the main problems associated with agricultural activities, due to the fact that nitrates are highly soluble and tends to percolate to soils and aquifers through run-off and easily reaches the surface waters as diffuse source (Grizzetti et al., 2012). 
As a consequence, these legislative initiatives have sought to limit environmental impacts through the designation of nitrate vulnerable zones (NVZ), to set up monitoring systems and to establish good agricultural practices. Other agro-environmental policies like CAP develops measures aimed to reduce surplus such as the reduction of nutrient inputs and the proper handling of fertilizers, the modification of cultivation techniques, the prevention of soil erosion and the maintenance of soil organic matter and structure.

Although approximately $43 \%$ of Veneto region is declared as NVZ, our results showed the existence of some hotspots, located both inside and outside the NVZs, with $\mathrm{N}$ surplus exceeding the application thresholds established by legislation to spread the manure on agricultural land (170 and $340 \mathrm{ha}^{-1}$ year $^{-1}$, respectively).

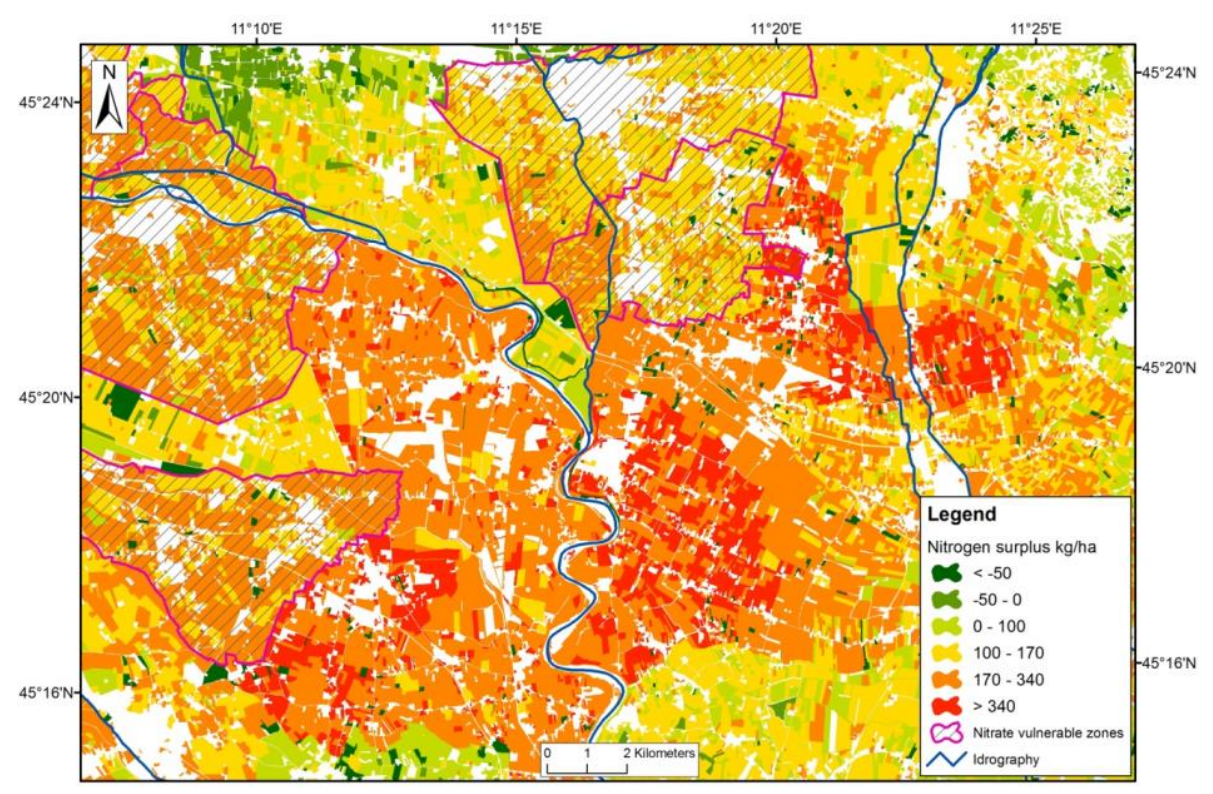

Figure 3. Areas of potential hotspots of nitrogen surplus near nitrate vulnerable zones

Therefore, the hotspots inside the NVZs demonstrate an incomplete effectiveness of mitigation policies and management, as well as the hotspots outside emphasize the need for additional studies aimed to improve the spatial zoning.

It should be remembered that the real nutrient loss pathways by diffuse sources are influenced by the climate and irrigation practices, increasing with precipitation (Grizzetti et al., 2012), therefore our results should be analyzed net of influence of weather fluctuation.

Furthermore, it should be stressed that nitrogen surplus could be misleading because it is affected by farm operational management decisions as manure management systems inside or outside the region, especially for the poultry manure (partially sent to treatment plants), which currently cannot be completely monitored.

Nonetheless, the applied methodology is shown to be adaptable to available data sources, while GISbased spatialisation approach can help to identify hotspots among ALUs and NVZs. Potentially, this new method could be the first step in identifying both appropriate and focused mitigation measures as well as the potential long term impact of the current agricultural practices, where an enhanced application of the legislation and policies may be more effective and efficient (Bassanino et al., 2011).

\section{Conclusions}

In this work, a gross nitrogen balance for Veneto region was computed and spatialised by using the available dataset provided by Regional and National authorities. The approach utilizes GIS to 
geographically delineate four agro-environmental land units within nitrogen budgets were calculated. Results evidenced that synthetic fertilizers and manure are the major sources of nitrate in the study area, with low contributions of nitrogen fixation and deposition. Significant differences between land units are linked to different agricultural systems and territorial management practices, resulting in different nitrogen sources, and therefore, nitrogen balances and use efficiency. The maps produced may be used directly by policy makers and land managers as a proxy to developing measures for decreasing environmental pressure and potential risk of pollution at regional scale.

Although the study was detailed, the conclusions drawn from the results may be biased by some methodological assumptions like land use classes association with crop statistics, and for the limited temporal resolution of the analysis (year 2007). Further advancements could be achieved by a multidisciplinary GIS approach based on an ecosystemic modeling of nitrate fate and transport in groundwater, making it possible to identify areas at greater potential risk and most vulnerable to pollution.

\section{References}

Aarts H.F.M., Habekotté B. and Van Keulen H. (2000), Groundwater recharge through optimized intensive dairy farms, Journal of Environmental Quality, 29, 738-743.

Balestrini R., Arese C., Delconte C.A., Lotti A. and Salerno F. (2011), Nitrogen removal in subsurface water by narrow buffer strips in the intensive farming landscape of the Po River watershed, Italy, Ecological Engineering, 37, 148-157. doi: 10.1016/j.bbr.2011.03.031.

Bartoli M., Racchetti E., Delconte C.A., Sacchi E., Soana E., Laini A., Longhi D. and Viaroli P. (2012), Nitrogen balance and fate in a heavily impacted watershed (Oglio River, Northern Italy): in quest of the missing sources and sinks, Biogeosciences, 9, 361-373. doi:10.5194/bg-9-361-2012.

Bassanino M., Sacco D., Zavattaro L. and Grignani C. (2011), Nutrient balance as a sustainability indicator of different agro-environments in Italy, Ecological Indicators, 11, 715-723. doi: 10.1016/j.ecolind.2010.05.005

Beaudoin N., Saad J.K., Van Laethem C., Machet J.M., Maucorps J. and Mary B. (2005), Nitrate leaching in intensive agriculture in Northern France: Effect of farming practices, soils and crop rotations, Agriculture, Ecosystems and Environment, 111, 292-310. doi: 10.1016/j.bbr.2011.03.031.

Borin M., Passoni M., Thiene M. and Tempesta T. (2010), Multiple functions of buffer strips in farming areas, European Journal of Agronomy, 32, 103-111. doi:10.1016/j.eja.2009.05.003

Boroomandan P., Khoramivafa M., Haghi Y. and Ebrahimi A. (2009), The Effects of Nitrogen Starter Fertilizer and Plant Density on Yield, Yield Components and Oil and Protein Content of Soybean (Glycine max L. Merr), Pakistan Journal of Biological Sciences, 12, 378-382. doi:10.3923/pjbs.2009.378.382.

Bouwman A.F., Van Drecht G. and Van der Hoek K.W. (2005), Global and regional surface nitrogen balances in intensive agricultural production systems for the period 1970-2030, Pedosphere, 15(2), 137-155.

Campling P., Terres J.M., Vande Walle S., Van Orshoven J. and Crouzet P. (2005), Estimation of nitrogen balances from agriculture for EU-15: spatialisation of estimates to river basins using the CORINE Land Cover, Physics and Chemistry of the Earth, Parts A/B/C 30(1-3), 25-34.

CEC (2000), Communication from the Commission to the Council and the European Parliament, Indicators for the Integration of Environmental Concerns into the Common Agricultural Policy, $\operatorname{COM(2000)} 20$ final, 26 January, Brussels, Belgium.

Cey E.E., Roudolph D.L., Aravena R. and Parkin G. (1999), Role of the riparian zone in controlling the distribution and fate of agricultural nitrogen near a small stream in southern Ontario, Journal of Contamination Hydrology, 37,45-67.

CRPA (2006), Progetto MeditAIRaneo: settore Agricoltura. Relazione finale. Technical report on the framework of the MeditAIRaneo project for the Agriculture sector, Reggio Emilia - Italia. (In Italian).

de Vries W., Rinds G.J., Kros J., Lesschen J.P., Bouwman A.L., Grizzetti B., Bouraoui F., Butterbach-Bahl K., Bergamaschi P. and Winiwarter W. (2011), Geographical variation in terrestrial nitrogen budgets across Europe, in: The European Nitrogen Assessment, edited by: Sutton M.A., Howard C.M., Erisman J.W., Billen G., Bleeker A., Grennfelt P., van Grinsven H. and Grizzetti B., Cambridge University Press, New York, 271-297. 
Di Lorenzo T., Brilli M., Del Tosto D., Galassi D.M.P. and Petitta M. (2012), Nitrate source and fate at the catchment scale of the Vibrata River and aquifer (central Italy): an analysis by integrating component approaches and nitrogen isotopes, Environmental Earth Sciences, 67(8), 2383-2398, doi:10.1007/s12665-012-1685-0.

EMEP (2000), The Co-operative Programme for Monitoring and Evaluation of the Long-Range Transmission of Air Pollutants in Europe. Database available online at: http://www.emep.int (Access 20/03/2013).

EUROSTAT (2013), Nitrogen balance in agriculture. Available online at: http://epp.eurostat.ec.europa.eu/statistics explained/index.php/Nitrogen balance in agriculture (Access 23/05/2013).

Fageria N.K., Baligar V.C. and Jones C.A. (2010), Growth and Mineral Nutrition of Field Crops. CRC Press, Taylor \& Francis Group, Third edition, pp 586.

FAO (2000), Fertilizers and their use. Fourth edition. Food and Agriculture Organization of The United Nations, Rome.

FAO (2011), Guidelines for the preparation of livestock sector reviews. Animal Production and Health Guidelines. No. 5. Food and Agriculture Organization of The United Nations, Rome.

Gaj R. and Bellaloui N. (2012), Evaluation of phosphorus and nitrogen balances as an indicator for the impact of agriculture on environment: A comparison of a case study from Poland and Mississippi US, Agricultural Sciences, 3, 317-329, doi: 10.4236/as.2012.32036.

Galloway J.N., Townsend A.R., Erisman J.W., Bekunda M., Cai Z., Freney J.R., Martinelli L.A., Seitzinger S.P. and Sutton M.A. (2008), Transformation of the nitrogen cycle: recent trends, questions and potential solutions, Science, 320(5878), 889-892, doi: 10.1126/science.1136674.

Giles J. (2005), Nitrogen study fertilizes fears of pollution, Nature, 433, 791, doi:10.1038/433791.

Gourley C.J.P., Aarons S.R. and Powell J.M. (2012), Nitrogen use efficiency and manure management practices in contrasting dairy production systems, Agriculture, Ecosystems \& Environment, 147, 73-81, doi:10.1016/j.agee.2011.05.011.

Grizzetti B., Bouraoui F. and Aloe A. (2012), Changes of nitrogen and phosphorus loads to European seas, Global Change Biology, 18, 769-782, doi:10.1111/j.1365-2486.2011.02576.x.

Gruber N. and Galloway J.N. (2008), An Earth-system perspective of the global nitrogen cycle, Nature, 451, 293296, doi:10.1038/nature06592.

ISTAT (2010), Istituto Nazionale di Statistica, VI Censimento generale dell'agricoltura Database available at: www.istat.it (Access 10/04/2013).

Ki-In Kim, Clay D.E., Carlson C.G., Clay S.A. and Trooien T. (2008), Do synergistic relationships between nitrogen and water influence the ability of corn to use nitrogen derived from fertilizer and soil?, Journal of Agronomy, 100(3), 551-556, doi: 10.2134/agronj2007.0064.

Kitchen N.R. and Goulding K.W.T (2001), On-farm technologies and practices to improve nitrogen use efficiency. Chapter 13. In: Nitrogen in the environment: sources, problems, and management. Follett R.F, Hatfield J.L (ed.) pp. 335-369. Eds. Amsterdam, the Netherlands, Elsevier.

Langeveld J.W.A., Verhagen A., Neeteson J.J., van Keulen H., Conijn J.G., Schils R.L.M. and Oenema O. (2007), Evaluating farm performance using agro-environmental indicators: recent experiences for nitrogen management in the Netherlands, Journal of Environmental Management, 82, 363-376, doi:10.1016/j.jenvman.2005.11.021.

Lassaletta L., Romero E., Billen G., Garnier J., García-Gómez H. and Rovira J.V. (2012), Spatialized N budgets in a large agricultural Mediterranean watershed: high loading and low transfer, Biogeosciences, 9, 57-70, doi:10.5194/bg-9-57-2012.

Leip A., Achermann B., Billen G., Bleeker A., Bouwman A.F., de Vries W., Dragosits U., Döring U., Fernall D., Geupel M., Herolstab J., Johnes P., Le Gall A.C., Monni S., Nevečeřal R., Orlandini L., Prud'homme M., Reuter H.I., Simpson D., Seufert G., Spranger T., Sutton M.A., van Aardenne J., Voß M. and Winiwarter W. (2011b), Integrating nitrogen fluxes at the European scale, in: The European Nitrogen Assessment, ed. Mark A. Sutton, Clare M. Howard, Jan Willem Erisman, Gilles Billen, Albert Bleeker, Peringe Grennfelt, Hans van Grinsven and Bruna Grizzetti. Published by Cambridge University Press 2011. Chapter 16, UK, 345-376.

Leip A., Britz W., Weiss F. and de Vries W. (2011a), Farm, land, and soil nitrogen budgets for agriculture in Europe calculated with CAPRI, Environmental pollution, 159(11), 3243-3253, doi:10.1016/j.envpol.2011.01.040. 
Liu C., Watanabe M. and Wang Q. (2008), Changes in nitrogen budgets and nitrogen use efficiency in the agroecosystems of the Changjiang River basin between 1980 and 2000, Nutrient Cycling in Agroecosystems, 80(1), 19-37, doi:10.1007/s10705-007-9118-2.

OECD (2008), Environmental Performance of Agriculture in OECD Countries Since 1990. Organisation for Economic Cooperation and Development (OECD), Paris, France.

Oenema O., Kros H. and de Vries W. (2003), Approaches and uncertainties in nutrient budgets: implications for nutrient management and environmental policies, European Journal of Agronomy, 20, 3-16, doi:10.1016/S1161-0301(03)00067-4

Piano di gestione dei bacini idrografici delle Alpi Orientali (2010), (In Italian). Available online at: www.alpiorientali.it (Access 05/05/2013).

Pieri L., Ventura F., Vignudelli M. and Rossi P. (2011), Nitrogen balance in a hilly semi-agricultural watershed in Northern Italy, Italian Journal of Agronomy, 6, No 1. doi:10.4081/ija.2011.e12.

Regione Veneto (2009), Piano di Tutela delle Acque della Regione del Veneto - DCR n.107 5/11/2009. (In Italian).

Regione Veneto (2012), Integrated Production Regulations (Standards agricultural techniques, year 2012), (In Italian), Database available online at: http://www.regione.veneto.it/static/www/agricoltura-eforeste/AllegatoBdecreto04.pdf (Access 23/04/2013).

Regione Veneto (2013), Regional geoportal, Spatial Data Infrastructure of Veneto region - Data Catalog, (In Italian), Database available online at: http://idt.regione.veneto.it/app/metacatalog/index?deflevel=1 (Access 20/04/2013).

Ronaghi A. and Ghasemi-Fasaei R. (2013), Soil-crop nitrogen relationships in maize grown on calcareous fields, Journal of Plant Nutrition,36(7), doi: 10.1080/01904167.2013.779704.

Saam H., Powell J.M., Jackson-Smith D.B., Bland W.L. and Posner J.L. (2005), Use of animal density to estimate manure nutrient recycling ability of Wisconsin dairy farms, Agricultural Systems, 84, 343-357, doi:10.1016/j.agsy.2004.06.020.

Soana E., Racchetti E., Laini A., Bartoli M. and Viaroli P. (2011), Soil Budget, Net Export, and Potential Sinks of Nitrogen in the Lower Oglio River Watershed (Northern Italy), CLEAN-Soil, Air, Water, 39(11), 956-965, doi:10.1002/clen.20100454.

Spiess E. (2011), Nitrogen, phosphorus and potassium balances and cycles of Swiss agriculture from 1975 to 2008 , Nutrient Cycling in Agroecosystems, 91(3), 351-365, doi 10.1007/s10705-011-9466-9.

Stark C.H. and Richards K.G. (2008), The continuing challenge of agricultural nitrogen loss to the environment in the context of global change and advancing research, Dynamic Soil, Dynamic Plant, 2, 1-12.

Sutton M.A., Howard C.M., Erisman J.W., Billen. G., Bleeker A., Grennfelt P., van Grinsven H. and Grizzetti B. (2011), The European Nitrogen Assessment. Cambridge University Press, New York, pp. 601.

U.S. EPA (2011), Reactive Nitrogen in the United States: An Analysis of Inputs, Flows, Consequences, and Management Options. A Report of the Environmental Protection Agency Science Advisory Board. EPA-SAB11-013, August 2011. Washington, DC. Available online at: http://yosemite.epa.gov/sab/sabproduct.nsf/WebBOARD/INCSupplemental?OpenDocument $\quad$ (Access 10/03/2013). 